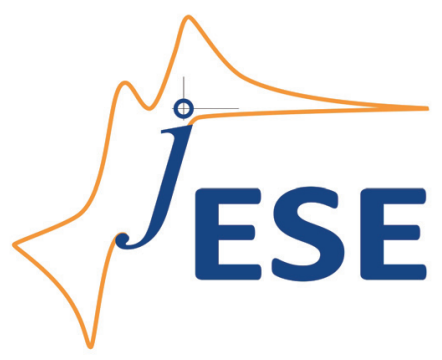

Open Access : : ISSN 1847-9286

www.jESE-online.org

Original scientific paper

\title{
Corrosion inhibition of carbon steel by sodium metavanadate
}

\author{
VIJAYA GOPAL SRIBHARATHY ${ }^{\varpi}$ and SUSAI RAJENDRAN*
}

Corrosion Research Centre, PG and Research Department of Chemistry, GTN Arts College, Dindigul-624005, Tamil Nadu, India

*Department of Chemistry, RVS School of Engineering and Technology, Dindigul-624005, Tamil Nadu, India

${ }^{\square}$ Corresponding Author: E-mail: bharathy chem@yahoo.co.in; Tel.: +91-451-2433262;

Fax: $+91-451-2433262$

Received: November 29, 2011; Revised: July 16, 2012; Published: August 30, 2012

\begin{abstract}
The inhibition efficiency of sodium metavanadate (SMV)-adipic acid (AA) system in controlling corrosion of carbon steel in an aqueous solution containing $60 \mathrm{ppm}$ of $\mathrm{Cl}^{-}$has been evaluated by weight-loss method; 250 ppm of SMV exhibits inhibition efficiency of $56 \%$. Addition of adipic acid to SMV improves the inhibition efficiency of the system. The formulation consisting of $250 \mathrm{ppm}$ of SMV and $250 \mathrm{ppm}$ of adipic acid has inhibition efficiency of $98 \%$. A synergistic effect exists between SMV and adipic acid with the synergism parameters greater than 1. Mechanistic aspects of corrosion inhibition have been studied by electrochemical methods like potentiodynamic polarization and electrochemical impedance spectroscopy. FTIR spectra reveal that the protective film consists of $\mathrm{Fe}^{2+}$-SMV complex and $\mathrm{Fe}^{2+}$-adipic acid complex. The protective film has been analyzed by fluorescence spectra, SEM and EDAX.
\end{abstract}

\section{Keywords}

Carbon steel, corrosion inhibition, fluorescence, synergism parameters, SEM, adipic acid, sodium metavanadate.

\section{Introduction}

Vanadium based oxy-anion, also referred to as vanadate, has been investigated as corrosion inhibitor for Al alloys [1-4]. Smith et al. explored the release kinetics and protection performance of vanadate based pigments in epoxy-coated AA 2014-T6 panels [5]. Cook et al. investigated several corrosion inhibitors including vanadates, molybdates and ions of rare earth elements like $\mathrm{Ce}, \mathrm{Y}$ and La [6]. Blanc et al. developed a surface conversion process for aluminium alloy based on acidic vanadium formulations which imparted protection to AA 2024-T3 coated panel [7]. These 
coating can be characterized by optical microscopy and scanning electron microscopy. Schumz and Frankel performed several AFM Scraching experiments on pure Al and AA 2024-T3 [8-10]. Buchheit et al. noticed that vanadates from the coating can impart active corrosion protection [11]. ${ }^{51} \mathrm{~V}$ nuclear magnetic resonance spectroscopy (NMR) has been used to prove that the inhibition efficiency of vanadate strongly depends on the speciation [12-14]. It was shown that the clear meta vanadate solutions inhibited AA 2024-T3 corrosion to an extent similar to chromate while orange decavanadate solution was poor inhibitor

\section{Experimental}

\section{Preparation of the specimens}

Carbon steel specimens, containing $0.02-0.03 \% \mathrm{~S}, 0.03-0.08 \% \mathrm{P}, 0.4-0.5 \% \mathrm{Mn}, 0.1-0.2 \% \mathrm{C}$, of the dimensions $40 \times 10 \times 2 \mathrm{~mm}$ were polished to a mirror finish, degreased with trichloroethylene, and used for weight-loss and surface examination studies. For potentiodynamic polarization studies, carbon steel encapsulated in Teflon, with an exposed cross section of $5 \mathrm{~mm}$ diameter, was used as the working electrode. The working electrode surface was polished to a mirror finish and it was degreased with trichloroethylene.

\section{Solution preparation}

Clear metavanadate solution was prepared by dissolving $1 \mathrm{~g} \mathrm{NaVO}_{3}$ in $100 \mathrm{ml}$ double distilled water. The adipic acid solution was prepared by dissolving $1 \mathrm{~g} \mathrm{COOH}-\mathrm{CH}_{2}-\mathrm{CH}_{2}-\mathrm{CH}_{2}-\mathrm{CH}_{2}-\mathrm{COOH}$ in $100 \mathrm{ml}$ double distilled water.

\section{Weight-loss method}

Three mild steel specimens were immersed for a period of three days in $100 \mathrm{ml}$ of the neutral aqueous test solutions (with a chloride content of $60 \mathrm{ppm}$ ) containing various concentrations of adipic acid as the inhibitor in the absence and presence of SMV. After the exposure, corrosion products were removed with Clarke's solution [15], and the weights of the specimens before and after the immersion were determined using a SHIMADZU AY62 electronic balance.

The percentage of inhibition efficiency (IE) was calculated using the following equation:

$I E=\frac{W_{1}-W_{2}}{W_{1}} 100$

$W_{1}=$ corrosion rate $(\mathrm{CR})$ in the absence of inhibitor and

$W_{2}=$ corrosion rate $(C R)$ in the presence of inhibitor

The corrosion rate was calculated using the following formula:

Corrosion rate, $\mathrm{mm}_{\text {year }}{ }^{-1}=\frac{\text { Loss in weight, } \mathrm{mg}}{\text { Surface area of specimen, } \mathrm{dm}^{2} \times \text { period of imersion, day }} \times \frac{0.0365}{\rho}$

$\rho$-density of the metal in $\mathrm{g} \mathrm{cm}^{-2}(7.86)$.

\section{Potentiodynamic polarization studies}

The polarization studies were carried out in a three-electrode cell assembly, using carbon steel as the working electrode, platinum as the counter electrode and saturated calomel electrode (SCE) as the reference electrode. Electrochemical impedance and polarization curve measurements were achieved using $\mathrm{H} \& \mathrm{CH}$ model $\mathrm{CHI} 660 \mathrm{~A}$ provided with iR compensation option. Polarization curve measurements were carried out at scan rate of $0.01 \mathrm{Vs}^{-1}$. The exposed area $\left(1 \mathrm{~cm}^{2}\right)$ was 
mechanically polished with a series of emery sheets of variable grade. The samples were washed thoroughly with double distilled water before insertion in the cell. During the polarization study, the scan rate was $0.01 \mathrm{~V} \mathrm{~s}^{-1}$; hold time at $E f$ was $0 \mathrm{~s}$ and quiet time was $2 \mathrm{~s}$.

\section{AC impedance spectra}

$A C$ impedance spectra were recorded using the same instrument as for polarization study and the same type of three electrode cell assembly. The real part $Z^{\prime}$ and imaginary part $Z^{\prime \prime}$ of the cell impedance were measured in $\Omega$ for various frequencies. The charge transfer resistance $\left(R_{\mathrm{t}}\right)$ and double layer capacitance $\left(C_{\mathrm{dl}}\right)$ values were calculated.

$$
\begin{aligned}
& R_{\mathrm{t}}=\left(R_{\mathrm{s}}+R_{\mathrm{t}}\right)-R_{\mathrm{s}} \\
& C_{\mathrm{dl}}=1 / 2 \pi R_{\mathrm{t}} f_{\max }
\end{aligned}
$$

where $R_{\mathrm{s}}=$ solution resistance, $f_{\max }=$ maximum frequency.

$A C$ impedance spectra were recorded with dc potential $E=0 \mathrm{~V}$, in the frequency range $1 \times 10^{5}$ $10 \mathrm{~Hz}$, amplitude $=0.005 \mathrm{~V}$, and quiet time $=2 \mathrm{~s}$.

\section{Analysis of the protective film}

The carbon steel samples were immersed in various test solutions for a period of three days. After three days samples were taken out and dried up. The film formed on the metal surface was carefully removed, mixed thoroughly with $\mathrm{KBr}$ and made as pellets samples which were recorded using Perkin Elmer FTIR 1600 spectrometer. The UV and Fluorescence spectra were recorded using Hitachi F-4500 fluorescence spectrophotometer. Surface analysis by SEM was recorded with JOEL MODEL 6390 to study the surface smoothness of the metal.

\section{Synergism parameter}

The synergism parameter can be calculated by using the equation indicating the synergistic effect existing between the inhibitors [16-18]:

$$
S_{\mathrm{i}}=\frac{1-\theta_{1+2}}{1-\theta_{1+2}^{\prime}}
$$

where $\theta_{1+2}=\left(\theta_{1}+\theta_{2}\right)-\left(\theta_{1} \theta_{2}\right)$,

$\theta_{1}=$ Surface coverage by substance 1

$\theta_{2}=$ Surface coverage by substance 2

$\theta_{1+2}^{\prime}=$ combined surface coverage for substance 1 and substance 2

Let the surface coverage be represented by $\theta ; \theta=I E / 100$.

If synergistic effect exists between the inhibitors, $S_{1}$ value will be greater than 1 .

Analysis of variance (F-test)

An F-test was carried out to investigate whether the synergistic effect existing between inhibitor systems is statistically significant [19]. If $F$-value is greater than 5.32 for 1,8 degrees of freedom, the synergistic effects proves to be statistically significant. If it is less than 5.32 for 1,8 degrees of freedom, it was statistically insignificant at a 0.05 level of significance. 


\section{Results and Discussion}

\section{Weight-loss method}

Corrosion rate of carbon steel in an aqueous solution containing $60 \mathrm{ppm}$ of $\mathrm{Cl}^{-}$in the presence and absence of inhibitor was obtained by weight loss method.

The inhibition efficiency is given in Table 1. It is observed that sodium metavanadate (SMV) has good inhibition efficiency (IE), i.e. as the concentration of SMV increases the inhibition efficiency also increases: $250 \mathrm{ppm}$ of SMV has $I E=56 \%$ and $250 \mathrm{ppm}$ of adipic acid (AA) has $I E=61 \%$, but the combination of $250 \mathrm{ppm}$ of SMV and $250 \mathrm{ppm}$ of adipic acids show IE $=98 \%$. This suggests a synergistic effect between the binary inhibitor formulation of SMV and AA.

Table 1. Corrosion rates (CR) of carbon steel in aqueous solution containing $60 \mathrm{ppm} \mathrm{Cl}^{-}$in the presence of inhibitor obtained by weight-loss method. Inhibitor: SMV - AA, immersion period: 3 days

\begin{tabular}{|c|c|c|c|}
\hline Amount of SMV, ppm & Amount of AA, ppm & $I E / \%$ & $C R / \mathrm{mm}_{\text {year }}{ }^{-1}$ \\
\hline 0 & 0 & - & 1.0374 \\
\hline 50 & 0 & 8 & 0.9544 \\
\hline 100 & 0 & 12 & 0.9544 \\
\hline 150 & 0 & 29 & 0.6933 \\
\hline 200 & 0 & 32 & 0.5765 \\
\hline 250 & 0 & 56 & 0.4564 \\
\hline 0 & 50 & 33 & 0.7261 \\
\hline 0 & 100 & 40 & 0.6221 \\
\hline 0 & 150 & 48 & 0.5390 \\
\hline 0 & 200 & 56 & 0.4564 \\
\hline 0 & 250 & 61 & 0.4044 \\
\hline 250 & 50 & 64 & 0.3697 \\
\hline 250 & 100 & 92 & 0.0826 \\
\hline 250 & 150 & 96 & 0.0411 \\
\hline 250 & 200 & 96 & 0.0411 \\
\hline 250 & 250 & 98 & 0.0310 \\
\hline
\end{tabular}

\section{Synergism parameter}

The value of synergism parameter is shown in Table 2 , here values of $S_{1}$ are greater than 1 suggesting a synergistic effect. $S_{\mid}$approaches 1 when no interaction exists between the inhibitor compounds. If $S_{1}>1$ it shows that the synergistic effect exists between the inhibitor compounds. In the case of $S_{1}<1$ the negative interaction of inhibitor prevails (i.e. the corrosion rate increases).

Table 2. Inhibition efficiencies and synergism parameters for various concentrations of AA-SMV (250 ppm) system, when carbon steel is immersed in aqueous solution containing $60 \mathrm{ppm}$ of $\mathrm{Cl}^{-}$. Immersion period: 3 days, $\mathrm{pH} 7$

\begin{tabular}{|c|c|c|c|c|c|c|c|c|}
\hline $\begin{array}{c}\text { Amount of } \\
\text { AA, ppm }\end{array}$ & $I E / \%$ & $\theta_{1}$ & $\begin{array}{c}\text { Amount of } \\
\text { SMV, ppm }\end{array}$ & $I E / \%$ & $\theta_{2}$ & $I_{1+2}^{\prime}$ & $\theta_{1+2}$ & $S_{1}$ \\
\hline 50 & 33 & 0.33 & 250 & 56 & 0.56 & 64 & 0.64 & 0.75 \\
\hline 100 & 40 & 0.40 & 250 & 56 & 0.56 & 92 & 0.92 & 3.3 \\
\hline 150 & 48 & 0.48 & 250 & 56 & 0.56 & 96 & 0.96 & 5.72 \\
\hline 200 & 56 & 0.56 & 250 & 56 & 0.56 & 96 & 0.96 & 4.84 \\
\hline 250 & 61 & 0.61 & 250 & 56 & 0.56 & 98 & 0.98 & 8.8 \\
\hline
\end{tabular}




\section{Analysis of variance (ANOVA)}

F-test is used to confirm if the synergistic effect existing between SMV and AA is statistically significant. The results are given in Table 3. The influence of various concentrations of adipic acid $(50,100,150,200,250 \mathrm{ppm})$ on the inhibition efficiency $250 \mathrm{ppm}$ of SMV is tested in Table 3 for the statistical significance. The observed F-value 6.17 is greater than the critical F-value (5.32) for 1,8 degrees of freedom at 0.05 level of significance so it was concluded that the synergistic effect existing between sodium metavanadate and $A A$ is statistically significant.

This is in agreement with conclusion derived from the calculation of synergism parameter.

Table 3. Distribution of F-Value between the inhibition efficiencies of the influence of SMV-AA

\begin{tabular}{|l|c|c|c|c|c|}
\hline \multicolumn{1}{|c|}{ Source of variance } & $\begin{array}{c}\text { Sum of } \\
\text { squares }\end{array}$ & $\begin{array}{c}\text { Degree of } \\
\text { freedom }\end{array}$ & $\begin{array}{c}\text { Mean } \\
\text { square }\end{array}$ & F & $\begin{array}{c}\text { Level of } \\
\text { significance }\end{array}$ \\
\cline { 1 - 4 } Between the sample & 1708 & 1 & 1708 & \multirow{2}{*}{6.17} & $\mathrm{p}<0.05$ \\
\hline With the sample & 521 & 8 & 278 & \\
\hline
\end{tabular}

\section{Analysis of FTIR spectra}

The FTIR spectrum of pure SMV is shown in Fig 1a. The vanadate stretching frequency of the sodium metavanadate appears at $1385 \mathrm{~cm}^{-1}$. The FTIR spectrum of pure adipic acid (AA) is shown in Fig $1 b$. The $-\mathrm{C}=\mathrm{O}$ stretching frequency appears at $1650 \mathrm{~cm}^{-1},-\mathrm{OH}^{-}$stretching frequency at $3413 \mathrm{~cm}^{-1}$, and $-\mathrm{CH}$ stretching frequency appears at $2900 \mathrm{~cm}^{-1}$. The FTIR spectrum of film formed on the carbon steel surface after immersion in solution containing $250 \mathrm{ppm}$ of SMV and $250 \mathrm{ppm}$ of adipic acid is shown in Fig. 1c. The vanadate frequency of sodium metavanadate increased from $1385 \mathrm{~cm}^{-1}$ to $1389 \mathrm{~cm}^{-1}$. The $-\mathrm{OH}^{-}$stretching frequency shifted from $3413 \mathrm{~cm}^{-1}$ to $3434 \mathrm{~cm}^{-1}$. The stretching frequency of carboxylic acid shifted from $1650 \mathrm{~cm}^{-1}$ to $1639 \mathrm{~cm}^{-1}$. This indicates that the oxygen atom of carboxyl group has coordinated with $\mathrm{Fe}^{2+}-\mathrm{AA}$ and $\mathrm{Fe}^{2+}-\mathrm{SMV}$ complex on the metal surface [20].

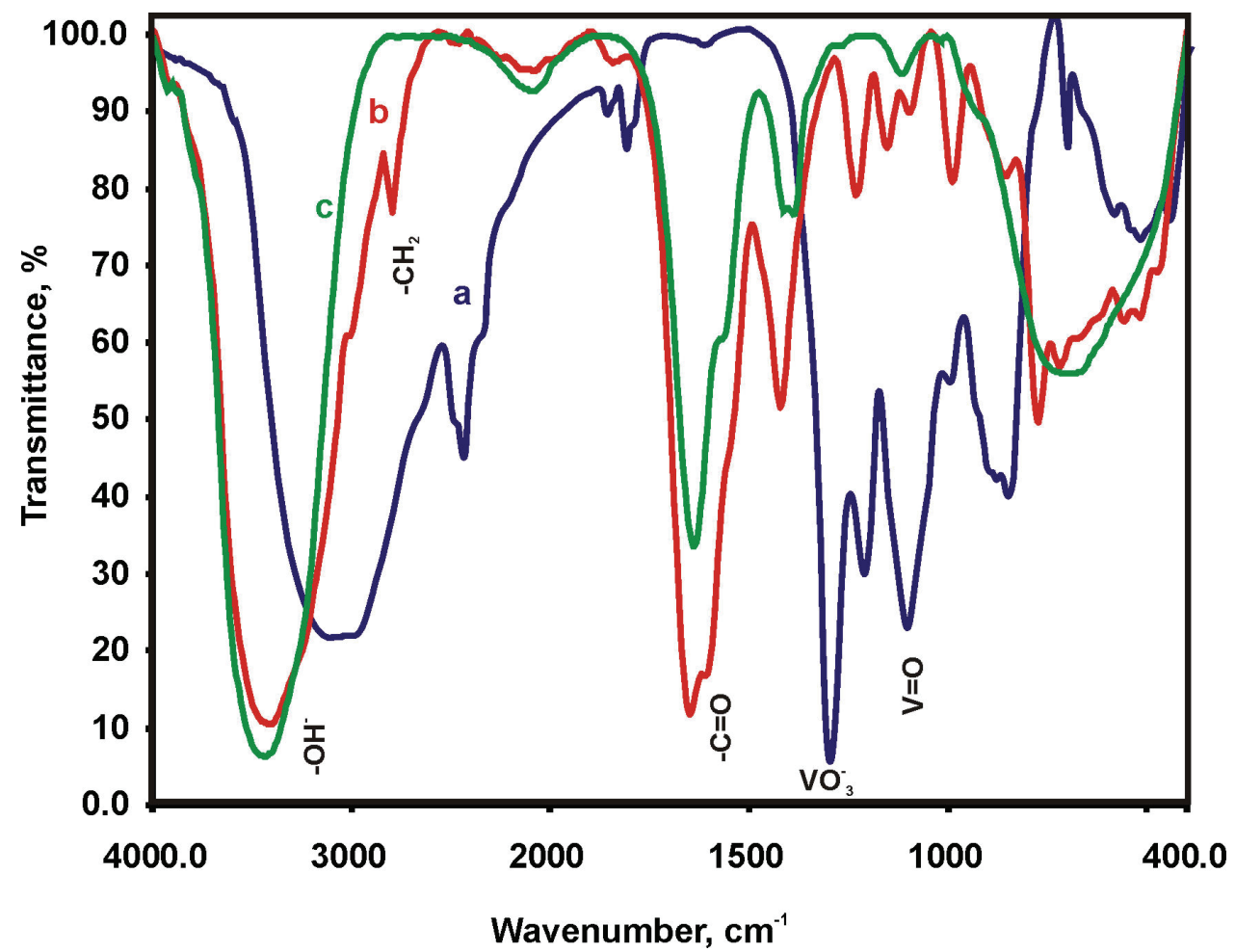

Figure 1. FTIR spectra of (a) Pure SMV. (b) Adipic Acid, (c) Film formed on the metal surface after immersion in the solution containing $50 \mathrm{ppm}$ of $\mathrm{Cl}^{-}+250 \mathrm{ppm}$ of $S \mathrm{MV}+250 \mathrm{ppm}$ of $A A$ 


\section{Analysis of fluorescence spectra}

The analysed formulation contains $250 \mathrm{ppm}$ of SMV and $250 \mathrm{ppm}$ of adipic acid. Its emission spectrum $\left(\lambda_{\mathrm{ex}}=300 \mathrm{~nm}\right)$ is shown in Fig 2a. The peak appears at $400 \mathrm{~nm}$.

Solution containing 250 ppm of SMV and 250 ppm of adipic acid were mixed with a few drops of freshly prepared $\mathrm{Fe}^{2+}$ ions (ferrous sulphate) solution. After drying, its emission spectrum $\left(\lambda_{\mathrm{ex}}=\right.$ $300 \mathrm{~nm}$ ) is shown in Fig 2b. The intensity of the peak shifted from 400 to $403 \mathrm{~nm}$ [21]. The increase in intensity of the peak is due to the fact that the metal surface, after the formation of the protective film, is very bright and the film is very thin. Only one peak is obtained. Hence it is inferred that the complex is somewhat highly symmetric in nature.
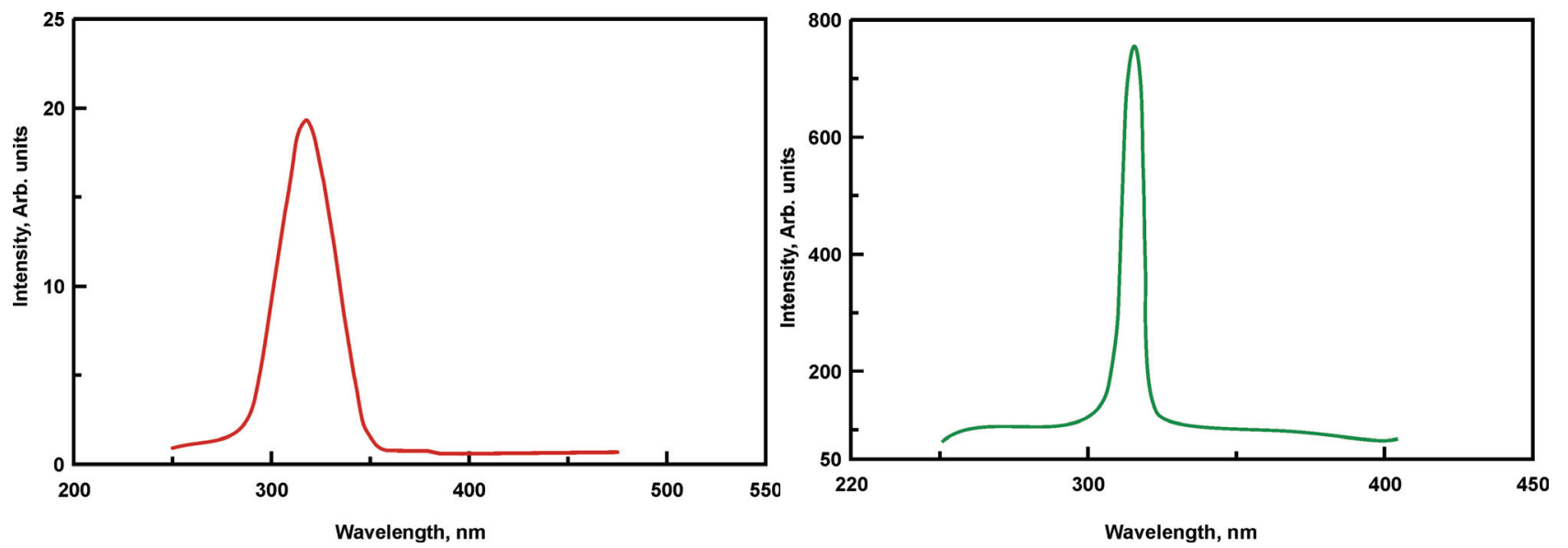

Figure 2. Fluorescence spectra of: (a) $S M V+F e^{2+}$, (b) $S M V+A A+F e^{2+}$

\section{Analysis of potentiodynamic polarization curve}

Polarization study has been carried out to confirm the formation of protective film formed on the metal surface during the corrosion inhibition process. If a protective film is formed on the metal surface, the linear polarization resistance value (LPR) increases and the corrosion current value $\left(I_{\text {corr }}\right)$ decreases.

The potentiodynamic polarization curves of carbon steel immersed in aqueous solution containing $60 \mathrm{ppm}$ of $\mathrm{Cl}^{-}$are shown in Fig. 3 and the corrosion parameters are given in Table 4. When sodium metavanadate and adipic acid were added to the above system, the corrosion potential shifted to the anodic sites of the metal surface. This film controls the anodic reaction by forming $\mathrm{Fe}^{2+}-\mathrm{SMV}$ and $\mathrm{Fe}^{2+}-\mathrm{AA}$ complex on the anodic sites of the metal surface.

The formation of a protective film on the metal surface is further supported by the fact that the anodic Tafel slope $\left(b_{\mathrm{a}}\right)$ increases from 198 to $288 \mathrm{mV}$. Furthermore, the linear polarization resistance (LPR) value increases from $2.0157 \times 10^{4} \Omega \mathrm{cm}^{2}$ to $4.0990 \times 10^{4} \Omega \mathrm{cm}^{2}$; the corrosion current decreases from $2.025 \times 10^{-6} \mathrm{~A} \mathrm{~cm}^{-2}$ to $1.120 \times 10^{-6} \mathrm{~A} \mathrm{~cm}^{-2}$. Thus the polarization study confirms the formation of the protective film on the metal surface [22-23].

Table 4. Corrosion parameters of carbon steel immersed in an aqueous solution containing $60 \mathrm{ppm}$ of $\mathrm{Cl}^{-}$in the absence and presence of inhibitors obtained by polarization method

\begin{tabular}{|c|c|c|c|c|c|c|}
\hline \multicolumn{2}{|c|}{ Amount of } & \multirow{2}{*}{$\begin{array}{c}E_{\text {corr }} \\
\mathrm{mV} v s . \mathrm{SCE}\end{array}$} & \multirow{2}{*}{$\begin{array}{c}b_{c} \\
\mathrm{mV}_{\text {decade }}{ }^{-1}\end{array}$} & \multirow{2}{*}{$\begin{array}{c}\mathrm{b}_{\mathrm{a}} \\
\mathrm{mV} \text { decade-1 }\end{array}$} & \multirow{2}{*}{$\begin{array}{c}\mathrm{I}_{\text {corr }} \\
\mathrm{A} \mathrm{cm}^{-2} \\
\end{array}$} & \multirow{2}{*}{$\mathrm{LPR} / \Omega \mathrm{cm}^{2}$} \\
\hline AA, ppm & SMV, ppm & & & & & \\
\hline 0 & 0 & -542 & 193 & 198 & $2.025 \times 10^{-6}$ & $2.0157 \times 10^{4}$ \\
\hline 250 & 250 & -554 & 166 & 288 & $1.120 \times 10^{-6}$ & $4.0990 \times 10^{4}$ \\
\hline
\end{tabular}




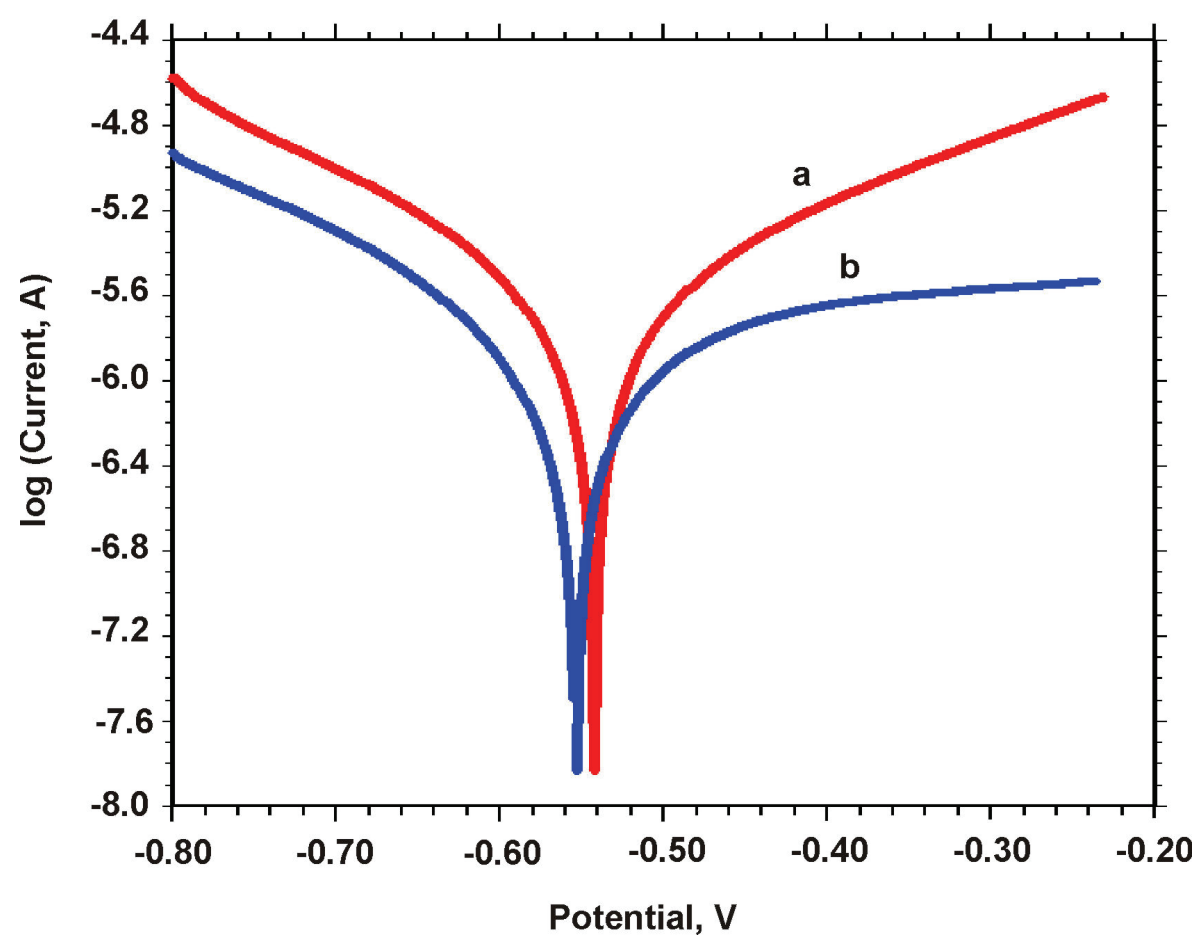

Fig.3. Polarization curves of carbon steel immersed in various test solutions

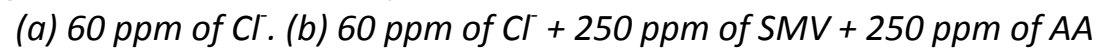

\section{Analysis of AC impedance spectra}

AC impedance spectra (electrochemical impedance spectra) have been carried out to confirm the formation of the protective film on the metal surface since charge transfer resistance $\left(R_{\mathrm{ct}}\right)$ increases, double layer capacitance value $\left(C_{\mathrm{dl}}\right)$ decreases and the impedance $\log (Z / \Omega)$ value increases. The $A C$ impedance spectra of carbon steel immersed in aqueous solution containing $60 \mathrm{ppm}$ of $\mathrm{Cl}^{-}$in the absence and presence of inhibitors are shown in Figs. 4a,b (Nyquist plots) and in Figs. 5a,b (Bode plots). The impedance $\log (Z / \Omega)$ values derived from Bode plots are also given in Table 4.

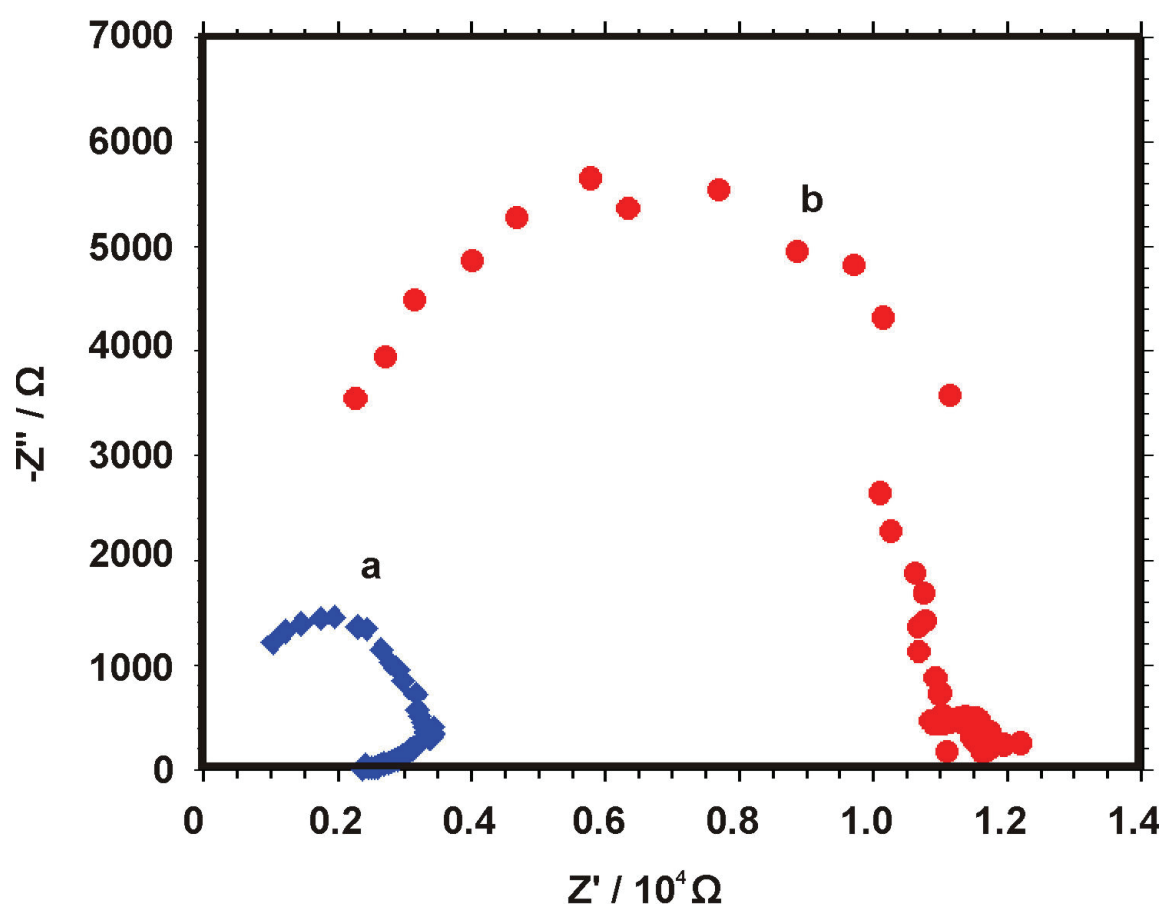

Figure 4. AC impedance spectra (Nyquist plot) of carbon steel immersed in various test solutions: (a) $60 \mathrm{ppm}$ of $\mathrm{Cl}$. (b) $60 \mathrm{ppm}$ of $\mathrm{Cl}+250 \mathrm{ppm}$ of $S M V+250 \mathrm{ppm}$ of $\mathrm{AA}$ 
AC impedance parameters, namely, charge transfer resistance $\left(R_{\mathrm{ct}}\right)$ and double layer capacitance $\left(C_{\mathrm{dl}}\right)$ are given in Table 5 for the aqueous solution containing $60 \mathrm{ppm}$ of $\mathrm{Cl}^{-}$. The obtained values are: $R_{\mathrm{ct}} 2500 \Omega \mathrm{cm}^{2}$ and $C_{\mathrm{dl}}$ value of $2.04 \times 10^{-8}$. When adipic acid and SMV are added to aqueous solution containing $60 \mathrm{ppm} \mathrm{Cl}^{-}, R_{\mathrm{ct}}$ value increases from $2500 \Omega \mathrm{cm}^{2}$ to $3500 \Omega \mathrm{cm}^{2}$. The $C_{\mathrm{dl}}$ value decreased from $2.04 \times 10^{-8}$ to $1.45 \times 10^{-8} \mathrm{~F} \mathrm{~cm}^{-2}$. This suggests that the protective film is formed on the metal surface.
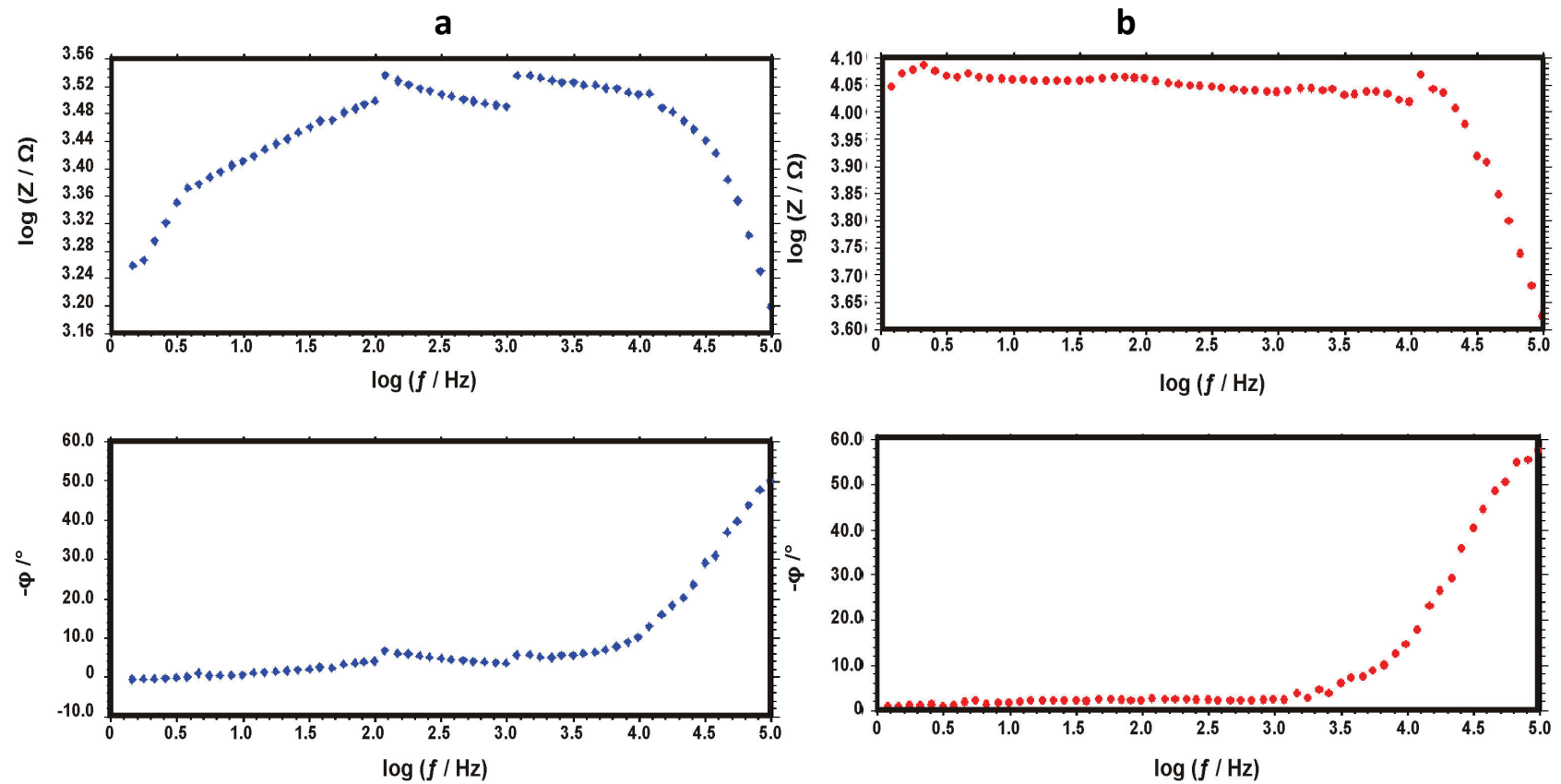

Figure 5. AC impedance spectra (Bode plots) of carbon steel immersed in various test solutions:

(a) 60 ppm of $\mathrm{Cl}^{-}$(b) 60 ppm of $\mathrm{Cl}^{-}+250$ ppm of SMV + 250 ppm of $A A$

Table 5 : Corrosion parameters of carbon steel immersed in an aqueous solution containing $60 \mathrm{ppm} \mathrm{Cl}^{-}$in the absence and presence of inhibitors obtained by AC impedance spectra

\begin{tabular}{|c|c|c|c|c|}
\hline \multirow{2}{*}{$\begin{array}{c}\text { Amount of } \\
\mathrm{AA}, \mathrm{ppm}\end{array}$} & \multirow{2}{*}{$\begin{array}{c}\text { Amount of } \\
\mathrm{SMV} \mathrm{ppm}\end{array}$} & \multicolumn{2}{|c|}{ Nyquist plot } & Bode plot \\
\cline { 3 - 5 } & $R_{\mathrm{t}} / \Omega \mathrm{cm}^{2}$ & $C_{\mathrm{dl}} / \mathrm{F} \mathrm{cm}^{-2}$ & $\log (Z / \Omega)$ \\
\hline 0 & 0 & 2500 & $2.04 \times 10^{-8}$ & 3.125 \\
\hline 250 & 250 & 3500 & $1.45 \times 10^{-8}$ & 3.44 \\
\hline
\end{tabular}

\section{Scanning electron microscopy (SEM)}

The SEM images of different magnification $(\times 500, \times 1000)$ of carbon steel specimen immersed in an aqueous solution containing $60 \mathrm{ppm} \mathrm{Cl}^{-}$for 3 days in the absence and presence of inhibitor systems are shown in Figs. $6(\mathrm{~b}, \mathrm{~d})$ and $6(\mathrm{c}, \mathrm{f})$, respectively.

The SEM micrographs of polished carbon steel in Figs. $6(a, b)$ show the smooth surface of the metal. The carbon steel surface immersed in aqueous solution containing $60 \mathrm{ppm} \mathrm{Cl}$, Figs. 6(b,d), shows the roughness of the metal surface that indicates the corrosion of carbon steel. Figs. $6(c, f)$ indicate that in the presence of inhibitor the rate of corrosion is suppressed, as it can be seen from the decrease of the corroded area. In the presence of SMV + AA, the surface is covered by a thin layer of inhibitors, which effectively controls the dissolutions of carbon steel [24]. 

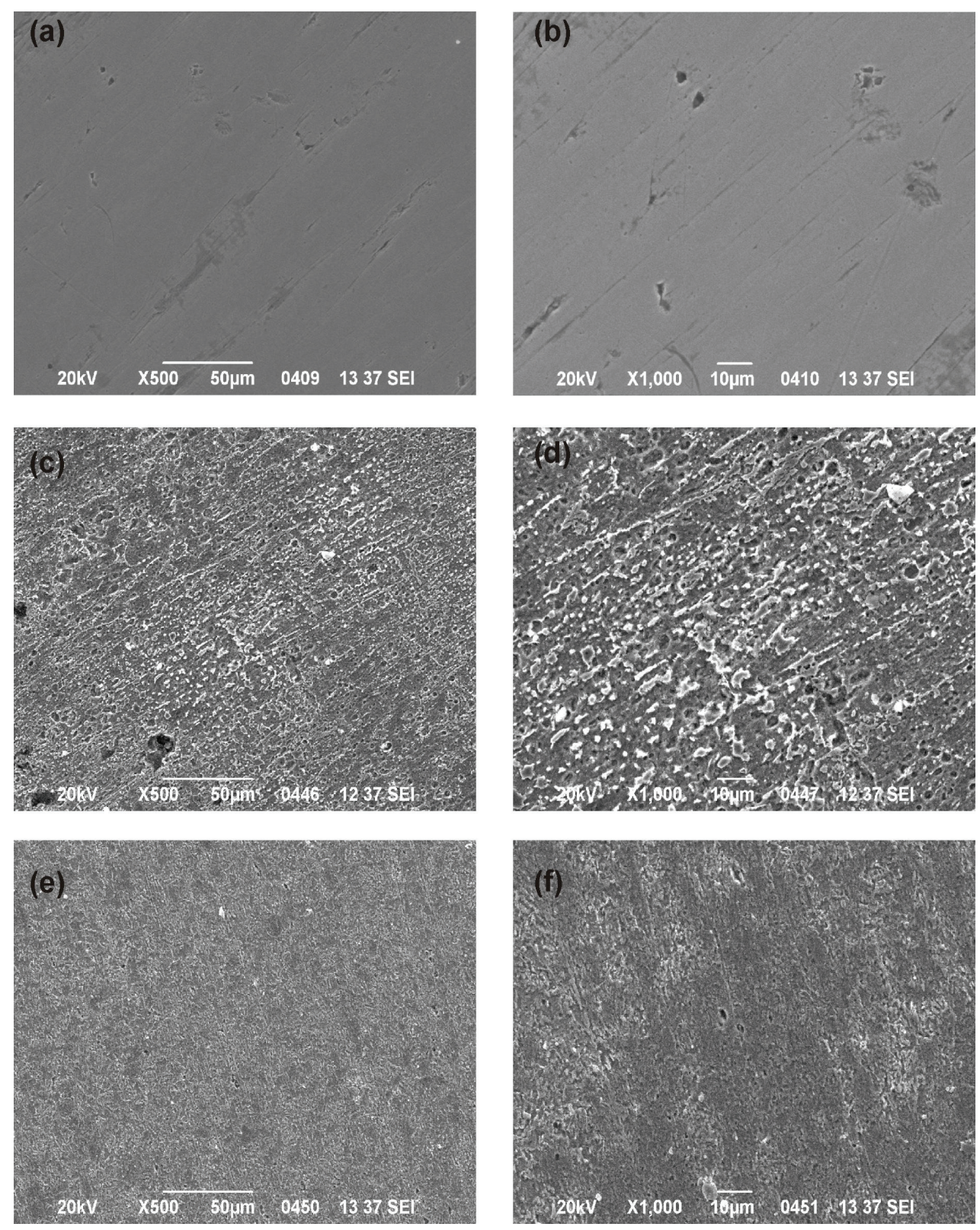

Figure 6. SEM micrographs of (a) Polished carbon steel (Control) (magnification X500);

(b) Polished carbon steel (Control) (magnification X1000),

(c) $60 \mathrm{ppm}$ of $\mathrm{Cl}^{-}$(magnification $\left.\times 500\right)$, (d) $60 \mathrm{ppm}$ of Cl (magnification $\left.\times 1000\right)$,

(e) $\mathrm{Cl} 60 \mathrm{ppm}+\mathrm{AA} 250 \mathrm{ppm}+\mathrm{SMV} 250 \mathrm{ppm}$ (magnification $\times 500$ ),

(f) $\mathrm{Cl} 60 \mathrm{ppm}+\mathrm{AA} 250 \mathrm{ppm}+\mathrm{SMV} 250 \mathrm{ppm}$ (magnification $\times 1000)$

\section{EDAX analysis}

EDAX analysis of various surfaces is shown in Fig. 7. The EDAX analysis of polished carbon steel is shown in Fig.7a.

The EDAX analysis of polished carbon steel immersed in an aqueous solution containing $60 \mathrm{ppm}$ of $\mathrm{Cl}^{-}, 250 \mathrm{ppm}$ of $\mathrm{AA}$ and $250 \mathrm{ppm}$ of SMV is shown in Fig. 7(b). Due to the formation of Feinhibitor complexes formed on the metal surface in presence of AA and SMV, the observed Fe signal is high in Fig 7a and low in Fig 7b. Thus the presence of vanadate on the metal surface is confirmed. It is also found that the intensity due to oxygen increases in Fig. 7b. This is due to the adsorption of carboxyl group of adipic acid of the inhibitor system. Thus it is concluded that the protective film consists of $\mathrm{Fe}^{2+}$-adipic acid complex and $\mathrm{Fe}^{2+}$-vanadate complex. 

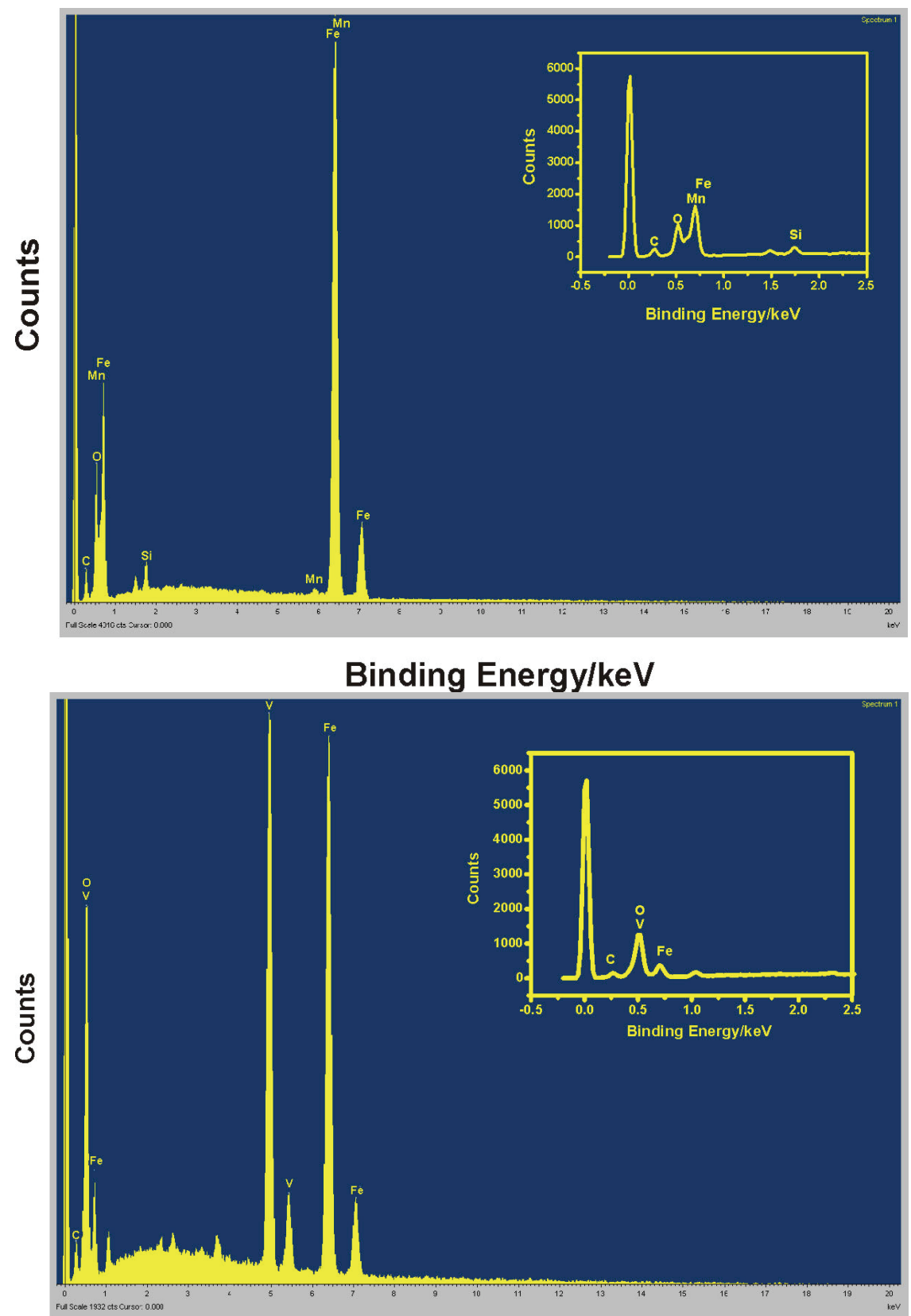

Binding Energy/keV

Figure 7. EDAX (a) Polished carbon steel (blank)

(b) Carbon steel in the solution containing $60 \mathrm{ppm} \mathrm{Cl}+250 \mathrm{ppm}$ of $\mathrm{AA}+250 \mathrm{ppm}$ of SMV

\section{Conclusions}

The corrosion inhibition by sodium metavanadate and adipic acid in aqueous solution containing $60 \mathrm{ppm}$ of $\mathrm{Cl}^{-}$in the presence and absence of inhibitor was studied by weight-loss study and electrochemical measurements. The results show that inhibitor has the ability of reducing the corrosion rate of carbon steel in aqueous solution containing $60 \mathrm{ppm}$ of $\mathrm{Cl}^{-}$, and it acts as an anodic inhibitor. This effectiveness is confirmed by electrochemical impedance spectra and potential polarization analysis. The SEM image in the presence of the inhibitor shows the formulation of the inhibitor layer. EDAX analysis revealed that vanadium is adsorbed on the metal surface. The formulation consisting of 250 ppm of SMV and 250 ppm adipic acid shows more than $96 \%$ inhibition efficiency and no pitting tendency. 
Acknowledgements: The authors are thankful to their respective Management and UGC for their encouragement and help.

\section{References}

[1] M. Kending, R.G. Buchheit, Corrosion (Houston), 59 (2003) 379-400.

[2] G.S. Frankel, H.S. Isaacs, J.R. Scully and J.D. Sinclair, eds., Corrosion Science : A

Retrospective and Current Status in Honour of Robert P. Frankenthal, PV 2002-13; p.430, The Electrochemical Society, Proceeding Series NJ (2002).

[3] H. Gaun,R.G. Buchheit, Corrosion (Houston), 60 (2004) 284-296.

[4] M. Trypuc and G. Lyjak, Polish J. App. Chem., XLI (Z3) (1997) 187-192.

[5] C.J.E. Smith, M.A.H. Hewins, P.L.Lane, K.R.Baldwin, M.C.Gibson in Proceeding of Eurocorr 98, Utrecht, The Netherlands, Paper N5 (1998).

[6] R.L. Cook, S.R. Taylor, Corrosion (Houston), 56 (2000) 321-333.

[7] C. Blanc, B. Lavelle, G. Mankowski, Corros. Sci., 39 (1997) 495-510.

[8] P. Schmutz, G.S. Frankel, J. Electrochem. Soc., 145 (1998) 2285-2295.

[9] P. Schmutz, G.S.Frankel, J. Electrochem. Soc., 145 (1998) 2295-2306.

[10] P. Schmutz, G.S.Frankel, J. Electrochem. Soc., 146 (1999) 4461-4472.

[11] R.G. Buchheit, H.Gaun, S. Mahajanam, F. Wong, Prog. Org. Coat., 47 (2003) 174-182.

[12] M. lannuzzi, T. Young, G.S. Frankel, J. Electrochem. Soc., 153 (2006) B533-B541.

[13] M. Iannuzzi, PhD. Dissertation, The Ohio State University, 2006.

[14] M. lannuzzi, G.S. Frankel, Corros. Sci., 49 (2007) 2371-2391.

[15] G. Wrangle, Introduction to corrosion and protection of metals.Chapman and Hall, London, 1986, p. 236.

[16] S. Rajendran, S. Vaibhavi, N. Anthony, D.C. Trivedi, Corrosion, 59 (2003) 529-534.

[17] S. Rajendran, A. John Amalraj, M.J. Joice, N. Antony, D.C. Trivedi, N. Sundaravadivelu, Corros. Rev., 22 (2004) 233-248.

[18] S. Rajendran, A. John Amalraj, B.R.E. Peter, P.P. Regis, A.M. Sundaravadivelu, Trans SAEST, 40 (2005) 35-39.

[19] S. Rajendran, A. Raji, A. Arokia Selvi, J. Rosaly, A. Thangaswamy, Edutracks, 6 (2007) 30-33.

[20] S. Rajendran, B.V. Apparao, N. Palaniswamy, Anti-Corros. Method. M., 47 (2000) 83-87.

[21] S. Rajendran, N. Palaniswamy, B.V. Apparao, in proceeding of the $8^{\text {th }}$ European symposium on corrosion inhibitors, University of Ferrara, Italy, (1996) 465.

[22] S. Rajendran, R.M. Joany, B.V. Apparao, N. Palaniswamy, Indian Journal Of Chemical Technology, 9 ( 2002) 197-200.

[23] R. Hariharaputhran, A. Subramanian, A.A. Antony, P. Manishanker, T. Vasudevan, S.V. Iyer, Anti-Corros. Method. M., 46 (1999) 35-39.

[24] R. Touir, N. Dkhireche, M. Ebn Touhami, M. Sfaira, O. Senhaji, J.J. Robin, B. Boutevin, M. Cherkaoui, Mater. Chem. Phys., 122 (2010) 1-9.

(C) 2012 by the authors; licensee IAPC, Zagreb, Croatia. This article is an open-access article distributed under the terms and conditions of the Creative Commons Attribution license

(http://creativecommons.org/licenses/by/3.0/) (cc) EY 